\title{
EFFECT OF DROUGHT ON MORPHOLOGICAL AND PHYSIOLOGICAL DEVELOPMENT OF BREAD WHEAT (Triticum aestivum L.) GENOTYPES AT PRE AND POST HEADING PERIOD
}

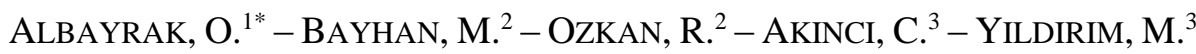 \\ ${ }^{1-3}$ Dicle University, Faculty of Agriculture, Department of Field Crops, Diyarbakir, Turkey \\ ${ }^{2}$ 100/2000 CoHE PhD Scholarship Program Student, Dicle University, Faculty of Agriculture, \\ Department of Field Crops, Diyarbakir, Turkey \\ *Corresponding author \\ e-mail: ondera@dicle.edu.tr; phone: +90-412-241-1000; fax: +90-412-241-1048
}

(Received $9^{\text {th }}$ May 2021; accepted $3^{\text {rd }}$ Sep 2021)

\begin{abstract}
The goal of the study was to determine the effect of drought on the bread wheat genotypes at pre-and post-heading stage. This research was conducted for two years in 2017-2018 and 2018-2019 wheat growing season at Dicle University Faculty of Agriculture Research and Application Field in Diyarbakir, Turkey. Two check varieties (Empire and Pehlivan) and 8 CIMMYT bread wheat lines were used as materials in the study. Significant differences in all features such as heading stage, chlorophyll content (SPAD), normalized difference vegatation index (NDVI), leaf area index (LAI), plant height, grain weight and grain yield between the genotypes were identified. Based on the results of the correlation analysis performed over the two-year average data; grain yield was found to be correlated with an increase of all the characteristics studied during the pre-heading period when drought stress were encountered. In terms of grain yield, late varieties are resistant to stress that occurs prior to heading, while early varieties have become advantageous after heading. According to the results of the study, ideal genotypes with high yield and stability are expected to have moderate heading stage in environments where precipitation fluctuates from year to year due to climate change.
\end{abstract}

Keywords: bread wheat, drought, stress, heading, yield

\section{Introduction}

Drought, one of the environmental stress factors, is the most important factor limiting crop production in rain-based agricultural areas in most of the world. Appropriate criteria should be developed for genotype evaluation to better understand how and in what way drought affects wheat yield in different development stages. Through this way, progress can be made towards the development of higher competitive genotypes, which will better respond to the dominant form of drought in area with certain ecological conditions (Ayranci, 2012). Drought tolerance in cool season cereals is rightly related to plants' ability to root deeply. The response of each genotype to drought varies depending on the stage of development. Drought in the early stages of development, decreases plant height, leaf area and number of fertile tiller; drought between stem elongation and spike formation, decreases number of fertile flowers in the spikelet, fertile spikelet in the spike and fertile spike; drought in the heading stage, decreases the number of grain in the spike; drought after flowering causes weight loss in the grain, while drought during the grain filling period leads to loss of grain in the tips and bottoms of the spike by increasing intraspike competition in terms of sharing the insufficient assimilates (Kutlu and Kinaci, 2010).

The effects of both heat and drought stress are expected to increase in dry-farming regions such as Central America, North Africa, Central Asia, Western Asia and Western 
Australia in the near future (IPCC, 2012). In Mediterranean climate regions, wheat is mostly grown in arid and semi-arid areas without irrigation, and plants are exposed to drougt and high temperatures during grain growth, resulting in major yield reductions. While the world population density rises day by day and the arable land declines, crop losses due to high temperatures have become increasingly critical in meeting the growing demand for food. The most important issue in plant breeding studies for drought tolerance is identifying the morphological and physiological response mechanisms used by plants to withstand water deficiency and drought. Developing the reactions of plants to stress caused by high temperatures and water deficiency, as aimed in this research, can be the basis for drought tolerance studies and can be used as a selection criterion for the selection of resistant plants. Today, there is a need to develop new wheat varieties that show high performance under drought and high heat stress. This need can only be met by focusing on crop and plant physiology features through interdisciplinary cooperation (Yildirim et al., 2009a).

In a study by Qaseem et al. (2019) was aimed to quantify effects of drought, heat and combined heat and drought during reproductive stage on wheat yield. Grain yield was reduced by $56.47 \%, 53.05 \%$ and $44.66 \%$ under combined heat and drought, heat and drought treatment, respectively.

Drought stress is a major abiotic stress factor, constraining wheat production and quality worldwide. Additionally, grain yield under stress and non-stress environments were highly correlated with the mean productivity, the geometric mean productivity, stress tolerance index, yield index, harmonic mean, drought resistance index and modified stress tolerance index (Ali and El-Sadek, 2016).

In this research, the effects of physiological and morphological properties on grain yield in bread wheat were investigated under conditions of drought that occurred before and after heading stage.

\section{Materials and methods}

This research was conducted for two years in 2017-2018 and 2018-2019 wheat growing season at Dicle University Faculty of Agriculture Research and Application Field in Diyarbakir (37 $53^{\prime}$ North and $40^{\circ} 16^{\prime}$ East), Turkey. Two check varieties (Empire and Pehlivan) and 8 CIMMYT bread wheat lines were used as materials in the study.

The results of some physical and chemical analysis of the soil of the experiment area are given in Table 1. The clay content of the soils is high and heavy. In addition, there are no significant problems with $\mathrm{pH}$, salinity and groundwater. The soil of the trial area is low in organic matter, alkaline ( $\mathrm{pH} 7.9)$ and clayey.

Some climate data are given in Table 2 for the two years (2017-2018, 2018-2019) that the study was conducted in. The first year of this study, while in the pre-heading period (December-April), plants received $268.40 \mathrm{~mm}$ of precipitation, in the same period the precipitation amounted to $604.80 \mathrm{~mm}$ in the second year. Since the average precipitation amount at the pre-heading stage was $429.50 \mathrm{~mm}$ over long term, the first year was exceptionally dry and the second year was exceptionally rainy. The precipitation was $172.20 \mathrm{~mm}$ during the 1st year of the study in the post-heading period (May-June), with the precipitation $46.80 \mathrm{~mm}$ in the $2^{\text {nd }}$ year of the study. Since the total long-term average precipitation amount is $52.20 \mathrm{~mm}$ in this period, the area where the study is conducted is subject to terminal drought stress. 
Table 1. Soil analysis results of the experiment area

\begin{tabular}{|c|c|c|c|c|}
\hline \multirow{2}{*}{\multicolumn{2}{|c|}{ Physical and Chemical Properties }} & \multicolumn{3}{|c|}{ Depth of soil } \\
\hline & & $0-30 \mathrm{~cm}$ & $30-60 \mathrm{~cm}$ & $60-90 \mathrm{~cm}$ \\
\hline \multirow{5}{*}{\multicolumn{2}{|c|}{$\begin{array}{c}\mathbf{p H} \\
\mathbf{P}_{2} \mathbf{O}_{5}(\%) \\
\text { Organic matter }(\%) \\
\text { Lime }(\%) \\
\text { EC }(\mathbf{d S} / \mathbf{m})\end{array}$}} & 7.7 & 7.9 & 7.8 \\
\hline & & 0.42 & -- & -- \\
\hline & & 1.67 & 1.67 & -- \\
\hline & & 7.8 & 7.8 & 8.7 \\
\hline & & 0.48 & 0.37 & 0.42 \\
\hline \multirow{4}{*}{ Soil structure } & Sand (\%) & 10 & 12 & 12 \\
\hline & Silt (\%) & 24 & 22 & 21 \\
\hline & Clay (\%) & 66 & 66 & 67 \\
\hline & Class Structure & $\mathrm{C}$ & $\mathrm{C}$ & $\mathrm{C}$ \\
\hline \multirow{4}{*}{\multicolumn{2}{|c|}{$\begin{array}{l}\text { Field Capacity }(\mathrm{g} / \mathbf{1 0} \mathrm{g}) \\
\text { Fading point }(\mathrm{g} / 100 \mathrm{~g}) \\
\text { Volume weight }(\mathrm{g} / \mathrm{cm} 3) \\
\text { İnf. Speed }(\mathrm{mm} / \mathbf{h})\end{array}$}} & 35.5 & 35.2 & 36.4 \\
\hline & & 25.5 & 25.3 & 27 \\
\hline & & 1.19 & 1.25 & 1.27 \\
\hline & & 8 & & \\
\hline
\end{tabular}

Table 2. The average monthly rainfall $(\mathrm{mm})$ and temperature $\left({ }^{\circ} \mathrm{C}\right)$

\begin{tabular}{c|c|c|c|c|c|c|c}
\hline \multirow{2}{*}{ STAGE } & \multirow{2}{*}{ Months } & \multicolumn{2}{|c|}{ Average Temperature $\left({ }^{\circ} \mathbf{C}\right)$} & \multicolumn{3}{|c}{ Precipitation (mm) } \\
\cline { 3 - 8 } & & $\mathbf{2 0 1 7 - 2 0 1 8}$ & $\mathbf{2 0 1 8 - 2 0 1 9}$ & Long years & $\mathbf{2 0 1 7 - 2 0 1 8}$ & $\mathbf{2 0 1 8 - 2 0 1 9}$ & Long years \\
\hline \multirow{5}{*}{ PRE } & October & 17.00 & 18.90 & 17.30 & 1.00 & 35.00 & 32.20 \\
& November & 10.10 & 10.20 & 9.50 & 21.20 & 59.00 & 54.20 \\
& December & 5.80 & 6.30 & 3.90 & 12.80 & 78.00 & 71.40 \\
HEADING & January & 5.20 & 3.80 & 1.70 & 86.60 & 67.60 & 70.30 \\
& March & 7.60 & 5.40 & 3.60 & 86.40 & 77.40 & 68.00 \\
& April & 12.30 & 8.20 & 8.40 & 11.60 & 135.20 & 65.10 \\
& Average & 9.40 & 11.80 & 13.80 & 48.80 & 152.60 & 68.30 \\
\cline { 2 - 8 } & Total & 73.90 & 7.62 & 6.82 & 44.57 & 94.97 & 66.22 \\
\hline \multirow{3}{*}{ POST } & May & 19.40 & 20.10 & 19.20 & 157.80 & 45.80 & 44.10 \\
HEADING & June & 26.50 & 28.30 & 26.20 & 14.40 & 1.00 & 8.10 \\
\cline { 2 - 8 } & Average & 22.95 & 24.20 & 22.70 & 86.10 & 23.40 & 26.10 \\
\cline { 2 - 8 } & Total & 45.90 & 48.40 & 45.40 & 172.20 & 46.80 & 52.20 \\
\hline
\end{tabular}

Although the pre-heading period was much hotter in the first year than the seasonal averages, the grain filling period was in seasonal norms. In the second year, except for the booting period, the pre-heading period was marginally above the seasonal average, while it was seen as stressful after the spike emergence (Table 2). The analysis of climate data shows that two different environments are formed. In this scenario, pre-heading period, the first year was assessed as extremely drought and heat stressful and high rainy and suitable climate post-heading period. In the second year, on the contrary of the first year, it was accepted as the environment with high rainfall and partially heat stressed for pre-heading, and moderate hot stress environment post-heading stage. Water content in the soil is high in the second year, based on the $239 \mathrm{~mm}$ of precipitation received before planting in the first year.

The experiment was established in both years with 4 replication according to the randomized completed block design. The parcel area was set to be $6 \mathrm{~m}^{2}(0.2 \mathrm{~m} \times 5 \mathrm{~m} \times 6$ rows) (Figure 1). Sowing was carried out in the first year on 15 December and the second year on 5 February, with a trial sowing machine, 500 seeds density per square meter. As a sowing fertilizer of $6 \mathrm{~kg} \mathrm{da}^{-1}$ nitrogen $(\mathrm{N})$ and $6 \mathrm{~kg} \mathrm{da}^{-1}$ phosphorus $\left(\mathrm{P}_{2} \mathrm{O}_{5}\right)$ was applied, 
while $6 \mathrm{~kg} \mathrm{da}^{-1}$ nitrogen $(\mathrm{N})$ at stem eleongation. In the study, for weed control (narrow and broad-leaved) were applied fenoxaprop-p-ethyl and Tribenuron-Methyl active substances herbicides. Harvesting was done in both years on July 17 by harvesting a $5 \mathrm{~m}^{2}$ area with the plot combine harvester. The heading stage in the characteristics examined was calculated as the number of days between the planting date and the period during which the spike appeared at $1 / 2$ in half of the plants in the plot. Plant height was determined by measuring the distance between the soil surface and the top spikelet tip in 10 plants in the plot by meter. The grain yield was calculated by weighing the seeds harvested with the parcel combine harvester and later counting one thousand grain $(\mathrm{g})$ in the grain counting machine. The normalized difference vegatation index (NDVI) has been calculated using Trimple Green Seeker (Trimble Navigation Limited, Sunnyvale, CA, USA), ranging between 0.00-0.99. The SPAD value (chlorophyll content) of the physiological properties examined in the study was measured with the SPAD-502 chlorophyll meter (Minolta Camera Co., Japan) device, and the leaf area index (LAI) was measured with the LAI-2000 (LI-COR, Lincoln, NE) device. SPAD, LAI and NDVI measurements were performed during the heading period, in sunny weather and between 11:00 and 14:00h, when there was no wind.
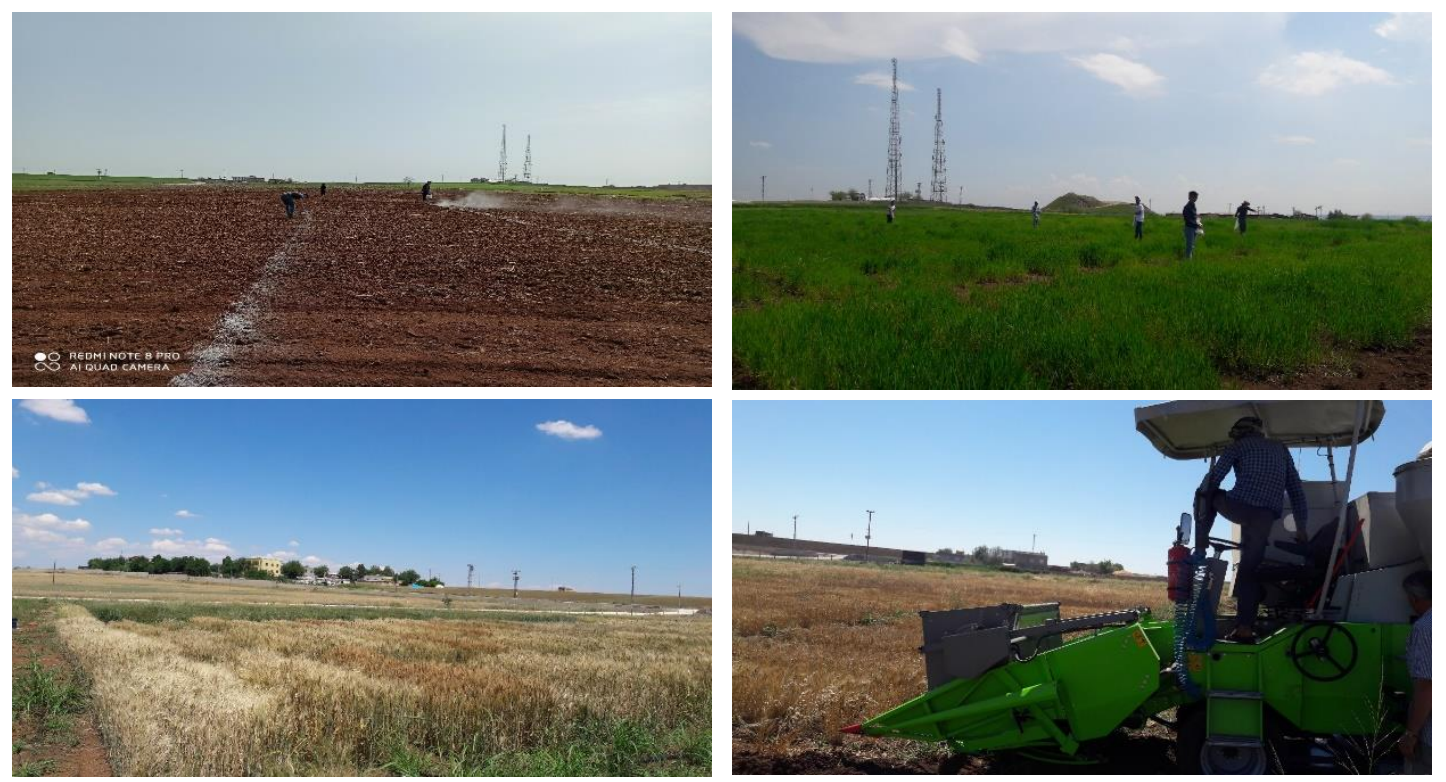

Figure 1. Images of the research field

Using JUMP Pro 13 statistical package software the data of the analyzed features were subjected to variance analysis and and the differences between the averages were revealed by LSD testing.

\section{Results and discussion}

\section{Heading stage (day)}

There were important variations between the bread wheat genotypes for the heading stage obtained by evaluating the amount of time spent from the emergence to the heading. The heading stage varied between 130.0-133.3 days in the first year and 96.3-105.3 days 
in the second year (Table 3). It was observed that DZ20-9 line with 130.0 days in first year and DZ20-3 line with 96.25 days in second year were the earliest genotype. The Pehlivan variety and DZ20-6 line were the most late genotypes in the first and second years, respectively. According to the average results of both years, the heading stage varied between 113.4-119.1 days and the DZ20-3 line was determined to be the earliest genotype. The fact that genotypes have different values for their heading stage in two years may be attributable to the emergence delay due to the first year's severe drought and genotypes having different biological characteristics. The fact that the earliness feature extends the grain filling time allows for greater assimilation accumulation in the grain and supports yield increase. According to the two-year average results; while the yield of the late varieties was low, it was determined that the medium-early varieties had high yields (Table 3). Yildirim et al. (2005) also notes that there is an increase in grain yield of early varieties. Blum (2010) shows that the earliness feature (early flowering) is the mechanism of drought escape, especially in the late developmental periods, however, late flowering implies higher yield potential, and early genotypes may experience decreased yields in environments where the drought arrival period is unpredictable, and therefore earlyness reported that it can be used to optimize phenology in more predictable environments. Yavas (2010) stated that wheat genotypes were started earlier heading in drought stress than stress-free conditions.

\section{SPAD value (chlorophyll content)}

SPAD measurements have demonstrated a strong association with chlorophyll derived from plants. There was no difference between bread wheat genotypes in both years in terms of chlorophyll content and SPAD values ranged between 44.63-51.08 in the first year and 41.93-46.75 in the second (Table 3). The fact that the genotype x year interaction is insignificant and that the genotypes with high chlorophyll content give similar results in both years reveal that this parameter is mostly under genotypic control and that the SPAD meter device can be used safely in selection by breeders. It is reported that by using the SPAD meter as a selection criterion in breeding programs, a genetic improvement in yield can be achieved (Yildirim et al., 2009b).

Yildirim et al. (2013) reported that the SPAD meter can be used in the selection of plants with high yield potential in both normal and heat stress conditions according to the measurements made during the milk grain growth stage in the bread wheat $\mathrm{F}_{2}$ segregation progenies. In the study of Yildirim et al. (2009b) on the use possibilities of chlorophyll content and canopy temperature in durum wheat breeding, they stated that there is a broad variation between genotypes and the chlorophyll content of each genotype may vary depending on the time of plant development. They determined that a genotype with low chlorophyll content among the different hybrid genotypes could increase the chlorophyll content in later ages of the plant. They reported that this could alter the ranking between genotypes by growing periods, and therefore it would be beneficial to perform selection in more than one period, rather than in a single measurement period. The SPAD value was found to be correlated with leaf chlorophyll and nitrogen, and critical values for maximum shoot growth were 53 when low water was given, and 44 for excess water values (Barraclough and Kyte, 2001). 
Table 3. Mean values for heading stage, SPAD, NDVI and LAI value of bread wheat genotypes

\begin{tabular}{|c|c|c|c|c|c|c|c|c|c|c|c|c|}
\hline \multirow[b]{2}{*}{ Genotypes } & \multicolumn{3}{|c|}{ Heading stage(day) } & \multicolumn{3}{|c|}{ SPAD value } & \multicolumn{3}{|c|}{ NDVI value } & \multicolumn{3}{|c|}{ LAI value } \\
\hline & $2017-2018$ & 2018-2019 & $\begin{array}{c}\text { Mean of } \\
\text { years }\end{array}$ & 2017-2018 & 2018-2019 & $\begin{array}{c}\text { Mean of } \\
\text { years }\end{array}$ & 2017-2018 & $2018-2019$ & $\begin{array}{c}\text { Mean of } \\
\text { years }\end{array}$ & $2017-2018$ & 2018-2019 & $\begin{array}{c}\text { Mean of } \\
\text { years }\end{array}$ \\
\hline DZ20-3 & $130.50 \mathrm{bc}$ & $96.25 \mathrm{~d}$ & $113.42 \mathrm{e}$ & 47.28 & 44.37 & 45.82 & 0.32 & $0.56 \mathrm{~cd}$ & $0.44 \mathrm{de}$ & 0.88 & $1.23 \mathrm{ab}$ & 1.05 \\
\hline DZ20-4 & $130.25 \mathrm{bc}$ & $97.50 \mathrm{~cd}$ & $113.88 \mathrm{de}$ & 46.4 & 44.38 & 45.39 & 0.31 & $0.56 \mathrm{~cd}$ & $0.44 \mathrm{e}$ & 0.63 & $1.05 \mathrm{~b}$ & 0.84 \\
\hline DZ20-5 & $130.75 b c^{1}$ & $102.00 \mathrm{ab}$ & $116.38 \mathrm{bc}$ & 50.78 & 46.37 & 48.57 & 0.33 & $0.57 \mathrm{~cd}$ & $0.45 \mathrm{c}-\mathrm{e}$ & 0.78 & $1.13 \mathrm{~b}$ & 0.95 \\
\hline DZ20-6 & $133.00 \mathrm{a}$ & $105.25 \mathrm{a}$ & $119.13 \mathrm{a}$ & 46.9 & 44.78 & 45.84 & 0.39 & $0.64 \mathrm{ab}$ & $0.51 \mathrm{ab}$ & 1.13 & $1.08 \mathrm{~b}$ & 1.10 \\
\hline DZ20-7 & $133.00 \mathrm{a}$ & $99.75 \mathrm{bc}$ & $116.33 \mathrm{bc}$ & 48.43 & 41.93 & 45.18 & 0.34 & $0.55 \mathrm{~cd}$ & $0.44 \mathrm{c}-\mathrm{e}$ & 0.95 & $1.13 \mathrm{~b}$ & 1.04 \\
\hline DZ20-8 & $131.00 \mathrm{bc}$ & $104.25 \mathrm{a}$ & $117.63 \mathrm{ab}$ & 48.17 & 42.55 & 45.36 & 0.37 & $0.59 \mathrm{~b}-\mathrm{d}$ & $0.48 \mathrm{bc}$ & 0.83 & $1.08 \mathrm{~b}$ & 0.95 \\
\hline DZ20-9 & $130.00 \mathrm{c}$ & $97.75 \mathrm{~cd}$ & $113.88 \mathrm{de}$ & 44.63 & 46.73 & 45.68 & 0.36 & $0.59 \mathrm{bc}$ & $0.48 \mathrm{~b}-\mathrm{d}$ & 0.87 & $1.08 \mathrm{~b}$ & 0.97 \\
\hline DZ20-10 & $131.00 \mathrm{bc}$ & $100.00 \mathrm{bc}$ & $115.50 \mathrm{~cd}$ & 46.43 & 43.53 & 44.98 & 0.35 & $0.54 \mathrm{~d}$ & $0.44 \mathrm{c}-\mathrm{e}$ & 1.03 & $0.73 \mathrm{c}$ & 0.88 \\
\hline Empire & $131.75 \mathrm{ab}$ & $99.50 \mathrm{~b}-\mathrm{d}$ & $115.63 \mathrm{~cd}$ & 48.95 & 46.75 & 47.85 & 0.36 & $0.57 \mathrm{~cd}$ & $0.46 \mathrm{c}-\mathrm{e}$ & 0.80 & $1.15 \mathrm{~b}$ & 0.98 \\
\hline Pehlivan & $133.25 \mathrm{a}$ & $105.00 \mathrm{a}$ & $119.13 \mathrm{a}$ & 51.08 & 43.73 & 47.4 & 0.39 & $0.66 \mathrm{a}$ & $0.52 \mathrm{a}$ & 0.95 & $1.50 \mathrm{a}$ & 1.23 \\
\hline Mean & $131.45 \mathrm{~A}$ & $100.72 \mathrm{~B}$ & 116.087 & 47.9 & 44.51 & 46.21 & $0.35 \mathrm{~B}$ & $0.58 \mathrm{~A}$ & 46.63 & 0.88 & 1.11 & 0.10 \\
\hline LSD & 1.74 & 3.32 & 1.82 & - & - & - & - & 0.047 & 0.04 & - & 0.30 & - \\
\hline $\mathrm{P}$ & $* *$ & $* *$ & $* *$ & - & - & - & - & $* *$ & $* *$ & - & $* *$ & - \\
\hline $\mathrm{CV}(\%)$ & 0.91 & 2.21 & 1.56 & 7.11 & 7.36 & 6.99 & 12.57 & 5.17 & 8.15 & 27.52 & 22.52 & 22 \\
\hline
\end{tabular}

LSD, least significant difference; ${ }^{1}$ : Means with the same letter are not significantly different; $\mathrm{CV}$, coefficient of variation; $\mathrm{P}$, Significance levels:*, $P<0.05 ; * *, P<0.01$ 


\section{NDVI value}

Spectral reflectance indices are valuable instruments for assessing the process of photosynthesis. NDVI is one of the commonly used canopy indices as an indicator of the surface green area which the plant covers and is directly related to the yield of grain (Kizilgeci et al., 2018). The NDVI has been associated with a variety of factors, including crop nutrient shortage, grain production, and long-term water stress. However, rather than representing the influence of a single component, NDVI must be seen as a composite measure of plant development that incorporates several plant growth variables (Verhults and Govaerst, 2010). The difference in NDVI value between genotypes was negligible in the first year, while significant was in the second year (Table 3). During the first year the NDVI value ranged from 0.31-0.39 and in the second year from 0.54-0.66. Pehlivan and DZ20-6 genotypes had the highest value in both years in terms of NDVI ranking. The lowest-value genotype were DZ20-10 at second year.

Looking at the two-year average values, NDVI ranged between 0.44 and 0.52 and genotypes with the highest value were similar in both years. The low NDVI values of the first year compared to the second year can be explained by the drought stress experienced in the first year of the study. The drought experienced in this period resulted in poor plant growth, decreased number of leaves, and shortened plant height. As a result, the vegetation density in the plot remained weak and the NDVI measurements were adversely affected by this situation. In this regard, NDVI measurements may not be effective in disclosing the difference between genotypes in drought environments before heading stage. Masuda et al. (2002) stated that the production of chlorophyll varied depending on the growth conditions of the plant, and that the amount of chlorophyll decreased under adverse conditions. It has been reported that there is a significant relationship between NDVI and biomass in wheat under full irrigation, supporting irrigation and rainfed conditions, particularly in the early periods between tillering and the start of the stem elengation period, and this relationship has disappeared in later periods and also an important relationship between the yield and NDVI values in rainfall and support irrigation has been reported (Savasli et al., 2012). Crusiol et al. (2017) stated that several factors such as the stage of measurement, the type of sensor and the environment affect the NDVI value.

\section{LAI (leaf area index) value}

In wheat, the leaf area index (LAI) gradually increases and quickly after emergence, reaching its peak value 2-3 weeks before flowering and gradually decreases as a result of leaf loss caused by maturity (Koc and Barutcular, 2000). In the first year of the study, analysis of variance of leaf area index of genotypes was found to be statistically insignificant, whereas in the second year of the study, it was statistically significant. Leaf area index values ranged between 0.63-1.13 in the first year and 0.73-1.50 in the second year. The highest leaf area index value was obtained in the from variety Pehlivan with 1.50. Drought experienced in the early stages of development in the first year of the study, resulting in a decrease in plant height, leaf area and fertile tiller.

While the LAI value varies depending on the plant's genotype and period of development (Kizilgeci et al., 2017), it is more important to determine the appropriate values for each genotype rather than the low or high LAI value, and it is recommended that varieties with a high HFA value be selected when more biomass is intended (Yildirim et al., 2018). The leaf area of the plants is significant in arid and semi-arid areas where 
water is inadequate in terms of resistance to drought. Varieties which do not have large leaf areas are preferred especially in arid areas (Okursoy, 2005).

\section{Plant height (cm)}

Average values of bread wheat genotypes for plant height are given in Table 4. In both years of the study, the difference between genotypes was found to be statistically significant. Plant height of genotypes varied between 37.6 and $44.2 \mathrm{~cm}$ in the first year and between 80.4 and $97.4 \mathrm{~cm}$ in the second year. In the study, the highest plant height values were obtained from DZ20-6 and DZ20-9 lines in the first year and from Empire variety with $97.4 \mathrm{~cm}$ in the second year. Whereas in the first year the average plant height of the genotypes was $40.2 \mathrm{~cm}$, in the second year it was $87.8 \mathrm{~cm}$ and a double value was observed compared with the first year. The differences in plant height between the two years may be attributed to the drought stress of the plants due to inadequate rainfall prior to heading in the 2017-2018 season of the experiment, and precipitation in the second year prior to heading was twice as high as in the previous year. It has been stated that water stress during the tillering period causes a decrease in plant height (Baloch et al., 2007). Plant height decreases due to low rainfall and high average temperature (Mut et al., 2006). Different studies showed that bread wheat's plant height decreased under the drought stress seen in different growth stages, and this decrease showed variability depending on the drought period and severity (Shamsi et al., 2010). Akinci (2003) stated that the plant height ranged between 51.6 and $113.7 \mathrm{~cm}$ in its study of 26 varieties of bread wheat.

\section{Grain weight (g)}

Thousand grain weight is a trait that is influenced by multiple genes, and varies depending on the genotype and environment (Dogan and Kendal, 2012). Thousand grain weights of the genotypes ranged from 27.22 to $35.67 \mathrm{~g}$ in the first year and from 26.57 to $34.0 \mathrm{~g}$ in the second year, and the variance between the varieties in both years was statistically important. Looking at Table 4, it is shown that the maximum grain weight value in the first year was obtained from the DZ20-6 line at $35.67 \mathrm{~g}$, and the lowest grain weight value was obtained from the DZ20-8 genotype at $27.22 \mathrm{~g}$. Table 4 reveals that the highest thousand grain weight value was obtained from a DZ20-6 line of $35.67 \mathrm{~g}$ in the first year and the lowest thousand grain weight from the DZ20-8 genotype with $27.22 \mathrm{~g}$. DZ20-4 was the highest thousand grain with a weight of $34.0 \mathrm{~g}$ in the second year, while DZ20-8 gave a weight of $26.57 \mathrm{~g}$ for the lowest grain weight. On average, grain weight were between $26.89 \mathrm{~g}$ and $31.78 \mathrm{~g}$ based on the two-year findings of the study. Although it was very dry and hot before heading period in the first year, after spike emergence high rainfall caused thousands of grain weights to grow. It has been recorded in studies of varieties and lines of bread wheat that thousands of grain weights ranged from 29.9-49.7 $\mathrm{g}$ (Sahin et al., 2005).

\section{Grain yield ( $\left.\mathrm{kg} \mathrm{ha}^{-1}\right)$}

In both years, variations between different wheat genotypes were found to be statistically significant at a level of $1 \%$ (Table 4). The highest grain yield was obtained from DZ20-6 line with $14.78 \mathrm{~kg} \mathrm{ha}^{-1}$ in the first year of the study, while the lowest grain yield was obtained from the genotypes DZ20-3 (8.05 $\left.\mathrm{kg} \mathrm{ha}^{-1}\right)$ and DZ20-4 (8.690 kg ha-1). The highest yield was obtained in the second year from DZ20-9 line at $30,09 \mathrm{~kg} \mathrm{ha}^{-1}$, 
while the lowest yield was obtained from DZ20-6 genotype at $20.12 \mathrm{~kg} \mathrm{ha}^{-1}$. Two-year average grain yield data varied between 15.98-20.97 $\mathrm{kg} \mathrm{ha}^{-1}$ and DZ20-7 and DZ20-9 genotypes yielded the highest grain yield. In a study conducted under similar conditions, the grain yield of bread wheat varieties varied between $29.96 \mathrm{~kg} \mathrm{ha}^{-1}$ and $73.29 \mathrm{~kg} \mathrm{ha}^{-1}$ (Yildirim et al., 2005). In the first growing season, the low total precipitation before heading caused drought stress and a very low yield of grain. In the second year of the study, flowering and grain filling period was negatively affected due to insufficient rainfall after the heading. The drought experienced in this period reduced the yield potential by causing both shortening of the grain filling period and the sterility of the upper spikelets. In the second year, despite the dry period after spiking, the higher grain yield in the first year may have been caused by the remobilization of the reserves accumulated in the stems and leaves before spiking. Early drought in wheat, it was recorded, has less impact than the drought in late development period and reduces the number of tillering, drought before heading stage reduces the number of fertile spikes, the number of spike grains and grain yield and the lowest yield is attributed to drought during grain filling (Abayomi and Wright, 1999).

Table 4. Mean values for plant height, grain weight and grain yield

\begin{tabular}{|c|c|c|c|c|c|c|c|c|c|}
\hline \multirow[b]{2}{*}{ Genotypes } & \multicolumn{3}{|c|}{ Plant height (cm) } & \multicolumn{3}{|c|}{ Grain weight (g) } & \multicolumn{3}{|c|}{ Grain yield (t ha-1) } \\
\hline & \begin{tabular}{|l|}
$2017-$ \\
2018
\end{tabular} & \begin{tabular}{|c|}
$2018-$ \\
2019 \\
\end{tabular} & $\begin{array}{c}\text { Mean of } \\
\text { years }\end{array}$ & $\begin{array}{l}2017- \\
2018 \\
\end{array}$ & $\begin{array}{c}2018- \\
2019 \\
\end{array}$ & $\begin{array}{c}\text { Mean of } \\
\text { years }\end{array}$ & $\begin{array}{l}2017- \\
2018\end{array}$ & $\begin{array}{c}2018- \\
2019 \\
\end{array}$ & $\begin{array}{c}\text { Mean of } \\
\text { years }\end{array}$ \\
\hline DZ20-3 & $37.6 \mathrm{e}$ & $91.87 \mathrm{ab}$ & $64.73 \mathrm{~b}-\mathrm{d}$ & $29.61 \mathrm{ef}$ & $32.30 \mathrm{ab}$ & $30.95 \mathrm{a}$ & $8.05 \mathrm{e}$ & $23.91 \mathrm{~b}$ & $15.98 \mathrm{e}$ \\
\hline DZ20-4 & $38.95 \mathrm{de}$ & & $60.08 \mathrm{e}$ & $29.17 \mathrm{ef}$ & $34.00 \mathrm{a}$ & $31.58 \mathrm{a}$ & $8.69 \mathrm{e}$ & $28.11 \mathrm{a}$ & $18.40 \mathrm{~b}-\mathrm{d}$ \\
\hline DZ20-5 & $40.87 b^{1}$ & $84.55 \mathrm{e}$ & $62.71 \mathrm{c}-\mathrm{e}$ & $28.57 \mathrm{fg}$ & $26.61 \mathrm{c}$ & $27.59 \mathrm{~b}$ & $13.59 \mathrm{~b}$ & $24.17 \mathrm{~b}$ & $18.88 \mathrm{bc}$ \\
\hline DZ20-6 & $44.2 \mathrm{a}$ & $80.45 \mathrm{e}$ & $62.33 \mathrm{~d}-\mathrm{e}$ & $35.67 \mathrm{a}$ & $26.98 \mathrm{c}$ & $31.32 \mathrm{a}$ & $14.79 \mathrm{a}$ & $20.12 \mathrm{c}$ & $17.45 \mathrm{c}-\mathrm{e}$ \\
\hline DZ20-7 & $41.2 \mathrm{~b}$ & $91.07 \mathrm{bc}$ & $66.13 \mathrm{ab}$ & $30.26 \mathrm{~d}-\mathrm{f}$ & $32.67 \mathrm{ab}$ & $31.46 \mathrm{a}$ & $11.59 \mathrm{c}$ & $30.35 \mathrm{a}$ & $20.97 \mathrm{a}$ \\
\hline DZ20-8 & $37.8 \mathrm{de}$ & $84.70 \mathrm{de}$ & $61.25 \mathrm{e}$ & $27.22 \mathrm{~g}$ & $26.57 \mathrm{c}$ & $26.89 \mathrm{~b}$ & $11.54 \mathrm{c}$ & $21.44 \mathrm{bc}$ & $16.49 \mathrm{e}$ \\
\hline DZ20-9 & $42.8 \mathrm{a}$ & $90.60 \mathrm{~b}-\mathrm{d}$ & $66.70 \mathrm{ab}$ & $31.81 \mathrm{~cd}$ & $32.02 \mathrm{ab}$ & $31.91 \mathrm{a}$ & $11.48 \mathrm{c}$ & $30.09 \mathrm{a}$ & $20.79 \mathrm{a}$ \\
\hline DZ20-10 & $40.65 \mathrm{bc}$ & $90.85 \mathrm{bc}$ & $65.75 \mathrm{a}-\mathrm{c}$ & $30.81 \mathrm{c}-\mathrm{e}$ & $30.46 \mathrm{~b}$ & $30.64 \mathrm{a}$ & $10.27 \mathrm{~d}$ & $28.70 \mathrm{a}$ & $19.49 \mathrm{ab}$ \\
\hline Empire & $39.23 \mathrm{~cd}$ & $97.40 \mathrm{a}$ & $68.31 \mathrm{a}$ & $32.32 \mathrm{bc}$ & $31.23 \mathrm{ab}$ & $31.78 \mathrm{a}$ & $11.78 \mathrm{c}$ & $28.58 \mathrm{a}$ & $20.18 \mathrm{ab}$ \\
\hline Pehlivan & $38.7 \mathrm{de}$ & $85.33 \mathrm{c}-\mathrm{e}$ & $62.02 \mathrm{de}$ & $33.88 \mathrm{~b}$ & $27.17 \mathrm{c}$ & $30.53 \mathrm{a}$ & $11.01 \mathrm{c}-\mathrm{d}$ & $22.31 \mathrm{bc}$ & $16.66 \mathrm{de}$ \\
\hline Mean & $40.20 \mathrm{~B}$ & $87.80 \mathrm{~A}$ & 64.00 & 30.93 & 30 & 30.47 & $11.28 \mathrm{~B}$ & $25.78 \mathrm{~A}$ & 18.53 \\
\hline LSD & 1.58 & 6.03 & 3.03 & 1.72 & 2.74 & 1.61 & 1.07 & 3.53 & 1.80 \\
\hline $\mathrm{P}$ & $* *$ & $* *$ & $* *$ & $* *$ & $* *$ & $* *$ & $* *$ & $* *$ & $* *$ \\
\hline $\mathrm{CV}(\%)$ & 2.71 & 5.06 & 4.74 & 3.84 & 6.53 & 5.28 & 6.53 & 9.44 & 9.7 \\
\hline
\end{tabular}

LSD, least significant difference; ${ }^{1}$ : Means with the same letter are not significantly different; CV, coefficient of variation; P, Significance levels: $*, P<0.05 ; * *, P<0.01$

The DZ20-6 line, which yielded the highest yield in the dry first year, increased by 36.06 percent in the second year and was more stable but yielded lower than other genotypes, according to Figure 2 showing the yield order of genotypes by rainfall amount. DZ20-7 lines, which yielded $11.59 \mathrm{~kg} \mathrm{ha}^{-1}$ in the first year, increased by $161.94 \%$ in the second year and yielded $30.35 \mathrm{~kg} \mathrm{ha}^{-1}$. This shows that this genotype has a general resistance to drought before and after heading. Among the genotypes, the DZ20-4 genotype with an increase of $223 \%$ was the most positive response to the total amount of precipitation before heading. Jana et al. (1990) reported that frequency of wheat population with early heading, early maturity and long grain filling period are considered as indicators of increase tolerance to drought. This strategy may be valid if stress is 
experienced throughout entire development period or before reproductive period. In this way, late-heading genotypes get the maximum yield during the first dry year because they continue to be stay-green throughout the growing stages and are better able to take advantage of late rains.

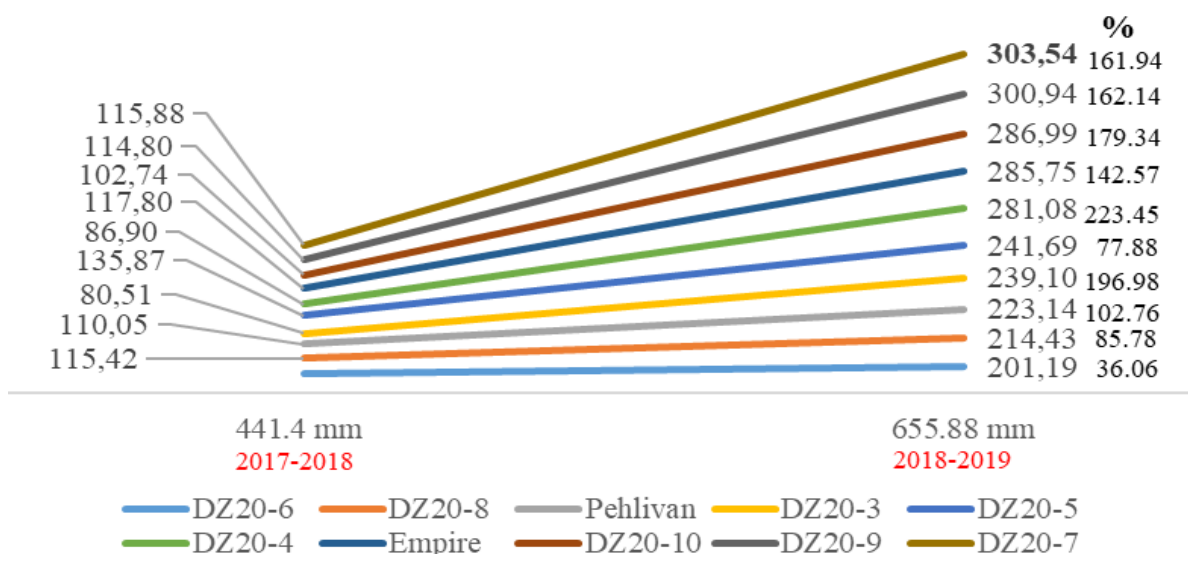

Figure 2. Two-season rainfall and seasonal yield changes

\section{Correlation analysis among investigated parameters}

The increase in all properties had a positive effect on the grain yield in the first year when drought and heat stress occurred in the pre-heading period, and a positive and significant relationship was found between grain yield and SPAD, plant height and thousand grain weight characteristics, in the second year (Table 5). Late genotypes provided a yield advantage in the first year due to the drought during the pre-heading period, whereas early genotypes were found to be advantageous in the second year due to drought after heading. Karaman et al. (2014) examined the relationship between physiological parameters and grain yield in some bread wheat varieties and found a strong association between grain yield and NDVI measurement. Yildirim et al. ( 2018) reported that grain yield was associated with NDVI and LAI among the physiological characteristics examined in bread wheat, but there was no significant relationship between grain yield and SPAD. Sakin et al. (2015) reported that there is a positive and significant relationship between grain yield and plant height in bread wheat, and the grain yield of tall varieties is high.

Table 5. The correlations between parameters

\begin{tabular}{|c|c|c|c|c|c|c|c|c|c|}
\hline \multirow[t]{2}{*}{ Parameters } & \multicolumn{2}{|c|}{$\begin{array}{l}\text { LAI } \\
\text { Value }\end{array}$} & \multicolumn{2}{|c|}{$\begin{array}{c}\text { Plant height } \\
\text { (cm) }\end{array}$} & $\begin{array}{l}\text { NDVI } \\
\text { Value }\end{array}$ & $\begin{array}{l}\text { Heading stage } \\
\text { (day) }\end{array}$ & \multicolumn{3}{|c|}{$\begin{array}{lc}\text { SPAD } & \text { Grain weight } \\
\text { Value } & (\mathrm{g}) \\
\end{array}$} \\
\hline & Year-I & Year II & Year-I & Year II & I Year-I Year II & I Year-I Year II & Year-I & Year II & Year-I Year II \\
\hline $\begin{array}{l}\text { Plant height } \\
\text { (cm) }\end{array}$ & $0.71 * *$ & 0.17 & & & & & & & \\
\hline NDVI Value & $0.81 * *$ & $0.60 * *$ & $0.76^{* *}$ & -0.02 & & & & & \\
\hline $\begin{array}{c}\text { Heading } \\
\text { stage }(\text { day })\end{array}$ & $0.69 * *$ & 0.22 & $0.53 * *$ & -0.24 & $0.66 * * 0.49 * *$ & & & & \\
\hline SPAD Value & $0.49 * *$ & 0.14 & $0.52 * *$ & 0.19 & $0.63 * * 0.09$ & $0.59 * *$ & & & \\
\hline $\begin{array}{c}\text { Grain } \\
\text { weight }(g)\end{array}$ & $0.59 * *$ & -0.07 & $0.54 * *$ & $0.39 *$ & $0.58 * *-0.33 *$ & $0.64 * *-0.65 * *$ & 0.28 & 0.16 & \\
\hline $\begin{array}{c}\text { Grain yield } \\
\left(\mathrm{kg} \mathrm{ha}^{-1}\right)\end{array}$ & $0.66 * *$ & 0.03 & $0.75^{* *}$ & $0.51 * *$ & $0.76 * *$ & $0.61 * * \quad-0.09$ & $0.53 * *$ & $0.52 * *$ & $0.52 * * 0.59 * *$ \\
\hline
\end{tabular}




\section{Conclusion}

Wheat yield varies depending on the annual precipitation as well as the distribution of precipitation. During the years of the research, the difference in the amount of precipitation in the wheat growing season before and after the heading offered an opportunity to test the genotype responses to different conditions.

When comparing late genotypes to early genotypes, it has been shown that the late genotypes are more productive in the dry season when there is precipitation during the grain filling phase.

To achieve stability and high yield potential in environments where seasonal precipitation fluctuates as a result of climate change, it would be beneficial to make the variety recommendation with mid-early varieties that produce the highest yield in both seasons rather than early and late genotypes.

Based on the findings, it will be possible to recommend to farmers mid-early genotypes DZ20-7 and Empire, which have demonstrated general stability and good production, as well as to assess them as parent in breeding studies.

Testing multiple genotypes in different locations will allow researchers to give a more accurate genotype recommendation to growers.

\section{REFERENCES}

[1] Abayomi, Y. A., Wright, D. (1999): Osmotic potential and temperature effects on germination of spring wheat (Triticum aestivum L.) genotypes. - Tropical Agriculture (Trinidad) 76(2): 120-125.

[2] Akinci, C. (2003): Comparison of some varieties and lines of bread and durum wheat. $-5^{\text {th }}$ Field Crops Congress of Turkey, 13- October 17, 2003, Field Crops Breeding, pp. 426-430.

[3] Ali, M. B., El-Sadek, A. N. (2016): Evaluation of drought tolerance indices for wheat (Triticum aestivum L.) under irrigated and rainfed conditions. - Communications in Biometry and Crop Science 11: 77-89.

[4] Ayranci, R. (2012): Determination of yield, physiological, morphological and quality parameters in bread wheat genotypes to be used in different drought types. - The Graduate School of Natural and Applied Science of Selcuk University, the Degree of Doctor of Philosophy in Department of Field Crops, Konya.

[5] Baloch, M. J., Veesar, N. F. (2007): Identification of plant traits for characterization of early maturing upland cotton varieties. - Pakistan Journal of Scientific and Industrial Research (Pak. J. Sci. \& Ind. Res.) 50: 128-132.

[6] Barraclough, P. B., Kyte, J. (2001): Effect of water stress on chlorophyll meter readings in winter wheat. - In: Horst, W. J. et al. (eds.) Plant Nutrition. Developments in Plant and Soil Sciences 92: 722-723. Springer, Dordrecht. https://doi.org/10.1007/0-306-47624-X_350.

[7] Blum, A. (2010): Plant breeding for water-limited environments. - Springer, London, 210p.

[8] Crusiol, L. G. T., de Fátima Corréa Carvalho, J., Sibaldelli, R. N. R. (2017): NDVI variation according to the time of measurement, sampling size, positioning of sensor and water regime in different soybean cultivars. - Precision Agric 18: 470-490. https://doi.org/10.1007/s11119-016-9465-6.

[9] Dogan, Y., Kendal, E. (2012): Determination of grain yield and some quality traits of some bread wheat (Triticum aestivum L.) genotypes in Diyarbakir ecological conditions. - YYU J Agr Sci 23(3): 199-208.

[10] IPCC. (2012): Managing the risks of extreme events and disasters to advance climate change adaptation. - In: Field, C. B. et al. (eds.) A special report of working groups I and II of the intergovernmental panel on climate change. Cambridge University Press, Cambridge, UK, and New York, NY, USA, 582p. 
[11] Jana, S., Srivastava, J. R., Damania, A. B., Clarce, J. M., Yang, R. C., Pecetti, L. (1990): Phenotypicdiversity and associations of some drought-related characters in durum wheat in the Mediterranean region. - In: Srivastava, J. P., Damania, A. B. (eds.) Wheat Genetic Resources: Meeting Diverse Needs. John Wiley and Sons, England, pp. 27-44. https://doi.org/10.2135/cropsci1991.0011183X003100060018x.

[12] Karaman, M., Akinci, C., Yildirim, M. (2014): Investigation of the relationship between grain yield with physiological parameters in some bread wheat varieties. - Trakya University Journal of Natural Sciences 15(1): 41-46.

[13] Kizilgeci, F., Akinci, C., Albayrak, O., Yildirim, M. (2017): Relationships of grain yield and some quality parameters with physiological parameters in some triticale advanced lines. - Igdır Univ. J. Inst. Sci. \& Tech. 7(1): 337-345.

DOI: https://doi.org/10.21597/jist.2017127446.

[14] Kizilgeci, F., Yildirim, M., Akinci, C., Albayrak, O., Sessiz, U., Tazebay, N. (2018): Evaluation of relationships between yield and yield components with physiological parameters in barley (Hordeum vulgare L.) genotypes. - DUFED 7(2): 61-66.

[15] Koc, M., Barutcular, C. (2000): Relationship between leaf area index at anthesis and yield in wheat under Cukurova conditions. - Turkish Journal of Agriculture and Forestry 24(5): 585-594. https://dergipark.org.tr/tr/pub/tbtkagriculture/issue/11655/138764.

[16] Kutlu, I., Kinaci, G. (2010): Evaluation of drought resistance indicates for yield and its components in three triticale cultivars. - Journal of Tekirdag Agricultural Faculty 7(2): 95103.

[17] Masuda, T., Polle, J. E. W., Melis, A. (2002): Biosynthesis and distribution of chlorophyll among the photosystems during recovery of the green alga Dunaliella salina from irradiance stress. - Plant Physiol. 128: 603-614.

[18] Mut, Z., Albayrak, S., Tongel, O. (2006): Determination of grain yield and some traits of triticale (Xtriticosecale Wittmack) lines. - Ankara University Faculty Of Agriculture, Agricultural Sciences Journal 12(1): 56-64.

[19] Okursoy, H. (2005): Determination of the economic irrigation level in Trakya conditions. - Trakya University Institute of Science, Master's Thesis, 80p., Tekirdag.

[20] Qaseem, M. F., Qureshi, R., Shaheen, H. (2019): Effects of Pre-Anthesis Drought, Heat and Their Combination on the Growth, Yield and Physiology of diverse Wheat (Triticum aestivum L.) Genotypes Varying in Sensitivity to Heat and drought stress. - Sci Rep 9: 6955. https://doi.org/10.1038/s41598-019-43477-z.

[21] Sahin, M., Aydogan, S., Akcacik, A. G., Taner, S. (2005): The evaluation on alveograf analysis of some bread wheat genotypes improved for the Central Anatolia. - Tagem journals 2: 1-9.

[22] Sakin, M. A., Naneli, İ., Goy, A. G., Ozdemir, K. (2015): Determination of yield and yield components of some bread wheat (Triticum aestivum L.) varieties at Tokat-Zile conditions. - Journal of Agricultural Faculty of Gaziosmanpasa University 32(3): 119-132. doi:10.13002/jafag927.

[23] Savasli, E., Cekic, C., Onder, O., Dayioglu, R., Kalayci, H. M. (2012): Evaluation of some bread wheat cultivars and advanced breeding lines for yield, biomass and vegetation index. - TABAD 5(2): 33-37. DOI: 10.13140/RG.2.1.4568.5522.

[24] Shamsi, K., Petrosyan, M., Noor-Mohammadi, G. (2010): The role of water deficit stress and water use efficiency on bread wheat cultivars. - J. Appl. Biosci. 35: 2325-2331.

[25] Verhulst, N., Govaerts, B. (2010): The normalized difference vegetation index (NDVI) GreenSeeker handheld sensor: Toward the integrated evaluation of crop management. Part A: Concepts and case studies. - Mexico, D.F.; CIMMYT.

[26] Yavas, I. (2010): The determination of drought resistance characters in Aegean Region's wheat cultivars. - Ph.D. Thesis, Department of Field Crops, 103p. Aydın.

[27] Yildirim, A., Sakin, M. A., Gokmen, S. (2005): Evaluation of some common bread wheat cultivars advanced and breeding lines for yield and yield components. - Gaziosmanpasa University Journal of the Faculty of Agriculture 22(1): 63-72. 


$$
\text { - } 4263 \text { - }
$$

[28] Yildirim, M., Bahar, B., Yucel, C., Genc, I. (2009a): Plant temperature variations in Cimmyt wheat yield experiment sets. - Turkey VIII. Field Crops Congress, 19-22 October 2009, Hatay, pp. 427-432.

[29] Yildirim, M., Akinci, C., Barutcular, C. (2009b): Applicability of canopy temperature depression and chlorophyl content in durum wheat breeding. - Anadolu J. Agric. Sci. 24: 158-166.

[30] Yildirim, M., Koc, M., Akinci, C., Barutcular, C. (2013): Variations in morphological and physiological traits of bread wheat diallel crosses under timely and late sowing conditions. - Field Crops Research 140: 9-17. https://doi.org/10.1016/j.fcr.2012.10.001.

[31] Yildirim, M., Kizilgeci, F., Akinci, C., Albayrak, O. (2018): Correlation analysis of LAI, SPAD, NDVI, CT with grain yield and quality traits of some bread wheat genotypes at heading stages. - Anatolia International Multidisciplinary Studies Congress, 22-29 December 2018, Diyarbakır, pp. 853-857. 